\title{
Temporal Changes in Concentrations of Some Trace Elements in Muscle Tissue of Crayfish, Astacus leptodactylus (Eschscholtz, 1823), from Keban Dam Lake
}

\author{
Onder Aksu, ${ }^{1}$ Ragip Adiguzel, ${ }^{2}$ Veysel Demir, ${ }^{3}$ Numan Yildirim, ${ }^{4}$ Durali Danabas, \\ Sebahat Seker, ${ }^{5}$ Safak Seyhaneyildiz Can, ${ }^{3}$ and Mustafa Ates ${ }^{6}$ \\ ${ }^{1}$ Fisheries Faculty, University of Tunceli, 62000 Tunceli, Turkey \\ ${ }^{2}$ Department of Chemical Engineering, Faculty of Engineering, University of Tunceli, 62000 Tunceli, Turkey \\ ${ }^{3}$ Department of Bioengineering, Faculty of Engineering, University of Tunceli, 62000 Tunceli, Turkey \\ ${ }^{4}$ Department of Environmental Engineering, Faculty of Engineering, University of Tunceli, 62000 Tunceli, Turkey \\ ${ }^{5}$ Department of Environmental Engineering, Faculty of Engineering, University of Ardahan, 75000 Ardahan, Turkey \\ ${ }^{6}$ Vocational School of Tunceli, University of Tunceli, 62000 Tunceli, Turkey
}

Correspondence should be addressed to Ragip Adiguzel; adiguzelragip@gmail.com

Received 27 October 2013; Accepted 11 January 2014; Published 23 February 2014

Academic Editor: Zhe-Sheng Chen

Copyright (C) 2014 Onder Aksu et al. This is an open access article distributed under the Creative Commons Attribution License, which permits unrestricted use, distribution, and reproduction in any medium, provided the original work is properly cited.

Crayfish (Astacus leptodactylus Eschscholtz, 1823) is the native crayfish species in Turkey. It was exported regularly to Western Europe. In this study, bioaccumulation and temporal trends of some trace elements (arsenic: As, cadmium: Cd, copper: $\mathrm{Cu}$, mercury: $\mathrm{Hg}$, lead: $\mathrm{Pb}$, and zinc: $\mathrm{Zn}$ ) in edible abdomen muscle of crayfish from Keban Dam Lake (Elazığ, Turkey) were investigated for the 2006-2012 period. Sequence of metal concentration levels was $\mathrm{Zn}>\mathrm{Cu}>\mathrm{Hg}>\mathrm{Pb}>\mathrm{Cd}>\mathrm{As}$ in muscle tissues. The highest concentration of $\mathrm{Zn}\left(21.69 \mathrm{mg} \mathrm{kg}^{-1}\right)$ was detected in 2006, while the lowest (4.35 mg kg$\left.{ }^{-1}\right)$ in 2009. In general, it was found that the concentrations of trace elements investigated were lower than the maximum permissible limits of the food regulations of the Ministry of Food, Agriculture, and Livestock (MFAL), the Turkish Food Codex and Commission Regulation (EC). If the crayfish selected for the study are recognized as bioindicators of environmental pollution, then it is possible to conclude that the changes in studied trace elements concentrations in the Keban Dam Lake are being steady.

\section{Introduction}

Many pollutants including trace elements are released from natural and anthropogenic sources into aquatic environments $[1,2]$. Accumulation of these elements in sediments, aquatic biota, and edible aquatic organisms is an important concern, because they are easily involved in food chain and affect most important reactions in living organisms, even at low concentrations $[1,3,4]$.

Copper $(\mathrm{Cu})$ can enter the environment through releases from the mining of $\mathrm{Cu}$ and other metals and from factories that make or use $\mathrm{Cu}$ metal or $\mathrm{Cu}$ compounds. Copper can also enter the environment through waste dumps, domestic waste water, combustion of fossil fuels and wastes, wood production, phosphate fertilizer production, and natural sources. One of the most commonly reported adverse health effect of $\mathrm{Cu}$ is gastrointestinal distress [5].

Cadmium (Cd) is emitted to soil, water, and air by nonferrous metal mining and refining, manufacture and application of phosphate fertilizers, fossil fuel combustion, and waste incineration and disposal. Cadmium can accumulate in aquatic organisms and agricultural crops. The U.S. Department of Health and Human Services (DHHS) has determined that $\mathrm{Cd}$ and $\mathrm{Cd}$ compounds are known human carcinogens [6].

Lead $(\mathrm{Pb})$ and $\mathrm{Pb}$ alloys are commonly found in pipes, storage batteries, weights, shot and ammunition, cable covers, and sheets used to shield us from radiation. The largest use for lead is in storage batteries in cars and other vehicles. Lead compounds are used as a pigment in paints, dyes, and 
ceramic glazes and in caulk. The amount of $\mathrm{Pb}$ used in these products has been reduced in recent years to minimize Pb's harmful effect on people and animals. Lead has long been known to alter the hematological system by inhibiting the activities of several enzymes involved in heme biosynthesis [7].

Mercury $(\mathrm{Hg})$ is a naturally occurring metal and enters the environment as the result of the normal breakdown of minerals in rocks and soil from exposure to wind and water, and from volcanic activity. Approximately $80 \%$ of the $\mathrm{Hg}$ released from human activities are elemental $\mathrm{Hg}$ released to the air, primarily from fossil fuel combustion, mining, and smelting and from solid waste incineration. About $15 \%$ of the total is released to the soil from fertilizers, fungicides, and municipal solid waste (e.g., from waste that contains discarded batteries, electrical switches, or thermometers). An additional 5\% is released from industrial wastewater to water in the environment [8].

Zinc $(\mathrm{Zn})$ is an essential human nutrient and a cofactor for over 300 enzymes and is found in all tissues. In humans, the highest concentrations of $\mathrm{Zn}$ have been found in bone, muscle, prostate, liver, and kidneys $[9,10]$. Large oral doses of $\mathrm{Zn}$ can interfere with $\mathrm{Cu}$ bioavailability as they compete for absorption, and clinical signs of immune dysfunction have been reported with daily doses in excess of $150 \mathrm{mg}$ [11].

The most essential component of life, water, being contaminated with arsenic is a global human health hazard. Millions of the populations worldwide are exposed to arseniccontaminated drinking water. Arsenic (As) is widely distributed in nature and released into the environment through natural sources, industrial processes, and agriculture usage [12]. Arsenic can affect human health and is considered one of the most significant environmental causes of cancer in the world [13]. Reference [14] reported that As is a unique carcinogen. It is the only known human carcinogen for which there is adequate evidence of carcinogenic risk by both inhalation and ingestion.

Some trace elements including $\mathrm{Zn}$ and $\mathrm{Cu}$ which are taken up by aquatic invertebrates both from food and solution are known to be essential elements and play important roles in biological metabolism at very low concentrations [15-18].

Others are known to be toxic, even at low concentrations, including aluminum $(\mathrm{Al}), \mathrm{As}, \mathrm{Cd}$, chromium $(\mathrm{Cr})$, iron $(\mathrm{Fe})$, manganese (Mn), $\mathrm{Hg}$, nickel (Ni), selenium (Se), $\mathrm{Zn}$, and $\mathrm{Pb}$ $[15,19]$. These elements can cause adverse effects on aquatic organisms, if these chemicals exist in biota and eventually build up to unacceptable levels in these organisms. Some trace elements are major contributor to crucial biochemical reactions in many living organisms such as fish and crustaceans $[1,20]$.

Generally crustaceans like all aquatic invertebrates accumulate metals from a wide range of sources and the trace metal concentrations within their tissues and bodies show great variability [21]. Crayfish can be used to monitor the aquatic environments for heavy metal pollution because they are solitary bottom dwellers, which keep much of their bodies in contact with surrounding objects and tend to accumulate metals in their tissues [22, 23]. These crayfish are used as a vector of contamination in many studies [3, 21, 22, 24, 25].

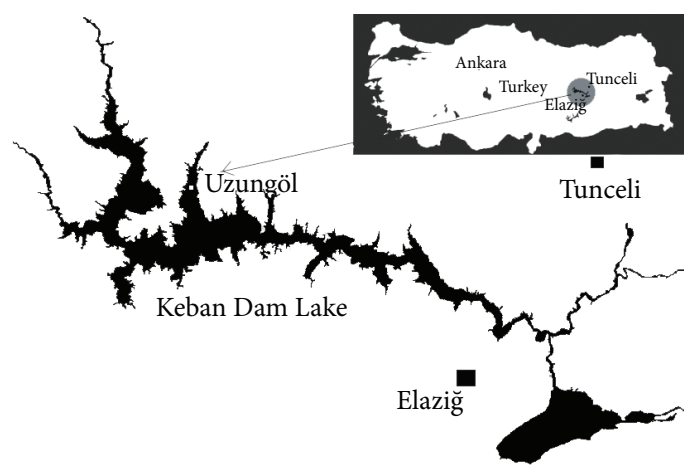

FIGURE 1: The map of sampling stations.

Due to negative effect of trace elements, their bioaccumulation in edible tissues of aquatic invertebrates needs to be monitored. The objective of this study is to determine temporally the bioaccumulation of trace elements in abdomen muscles of crayfish, Astacus leptodactylus, which is sea food having a great attraction in human consumption.

\section{Materials and Methods}

2.1. Properties of Sampling Area. The Keban Dam Lake, which is a hydroelectric dam on the river Euphrates, is located between the cities of Elazı $\breve{g}$ and Tunceli. The surface area of Keban Dam Lake is $687.31 \mathrm{~km}^{2}$. It is situated at latitude $38^{\circ} 5^{\prime} \mathrm{N}$ and $38^{\circ} 4^{\prime}$ E longitude at an elevation of $1134 \mathrm{~m}$ above sea level. This study was conducted in region with the sampling site coordinates of N $38^{\circ} 57^{\prime} 09^{\prime \prime}$ E $38^{\circ} 53^{\prime} 19^{\prime \prime}$ on Keban Dam Lake (Figure 1).

Near the sampling area, there are some metal processing industries that contribute to pollution of Keban Dam Lake. The effluent from Elazıg city sewage treatment facility is discharged to Keban Dam Lake. There are also some cage aquaculture facilities around sampling area.

2.2. Crayfish Sampling. The freshwater crayfish (A. leptodactylus) were caught by fyke nets in sampling area from Keban Dam Lake (Figure 1) each year in June and July from 2006 to 2012. The samples were sealed via plastic bags and transferred to the laboratory under cold chains. For each year, twenty five crayfish have approximately the same weight and length (same condition index) and were selected randomly among crayfish that is bigger than $10 \mathrm{~cm}$, legal catching length, and the abdomen muscles of crayfish were dissected. The abdomen muscles of all crayfish were homogenized with tissue homogenizer and used for trace element determination.

2.3. Analysis. The concentrations of trace elements were measured with ICP MS (Perkin Elmer Germany) according to the methods (no. 161) described by NMKL [26] in Food Control Laboratory in Izmir (Turkey). The concentrations obtained from the analyses were compared with the same tissue (muscle) and species (crayfish) in MFAL and EC. The 
TABLE 1: The levels of trace elements in abdomen muscles of crayfish (A. leptodactylus Eschscholtz, 1823) between 2006 and 2012 in Keban Dam Lake (Elazı̆g, Turkey).

\begin{tabular}{lccccccc}
\hline $\begin{array}{l}\text { Trace elements } \\
\left(\mathrm{mg} \mathrm{kg}^{-1}\right)\end{array}$ & 2006 & 2007 & 2008 & 2009 & 2010 & 2011 & 2012 \\
\hline $\mathrm{As}$ & 0.037 & $\mathrm{UDL}^{*}$ & UDL & UDL & UDL & 0.146 & $\mathrm{UDL}$ \\
$\mathrm{Cd}$ & 0.01 & UDL & 0.02 & UDL & 0.01 & UDL & 0.01 \\
$\mathrm{Cu}$ & 7.20 & 5.28 & 4.39 & 2.42 & 3.81 & 4.74 & 6.967 \\
$\mathrm{Hg}$ & 0.193 & 0.160 & 0.059 & 0.016 & 0.150 & 0.983 & 0.418 \\
$\mathrm{~Pb}$ & 0.03 & UDL & UDL & UDL & 0.01 & 0.04 & 0.08 \\
$\mathrm{Zn}$ & 21.69 & 17.95 & 16.22 & 4.35 & 14.60 & 16.04 & 21.65 \\
\hline
\end{tabular}

*UDL: under detection limit.

detectable limits of elements were $0.003,0.001,0.05,0.01,0.01$, and $0.01 \mathrm{mg} \mathrm{kg}^{-1}$ for $\mathrm{As}, \mathrm{Hg}, \mathrm{Zn}, \mathrm{Cd}, \mathrm{Cu}$, and $\mathrm{Pb}$, respectively.

\section{Results and Discussions}

The concentrations of trace elements in abdomen muscles of crayfish were shown in Table 1 . The highest $\mathrm{Zn}$ and $\mathrm{Cu}$ accumulation was measured as 21.69 and $7.2 \mathrm{mg} \mathrm{kg}^{-1}$, respectively, in 2006. There is a decrease in the concentration of both metals between 2006 and 2009 and an increase in following years. The levels of As were detected only in 2006 and 2011. The As, Cd, and Pb bioaccumulation levels were measured under the detectable limits for most of the samples analyzed. In general, there is an increase in mercury bioaccumulation level. The highest levels of $\mathrm{Cu}$ and $\mathrm{Cd}$ were determined in 2006 and 2008, while the lowest levels were determined in 2009. The antagonism between $\mathrm{Cu}$ and $\mathrm{Cd}$ was observed.

A. leptodactylus is the native crayfish species in Turkey. It was exported regularly to Western Europe, although domestic consumption of $A$. leptodactylus was very little. There has been an increase in the production of A. leptodactylus in recent years. One of the introduced populations of A. leptodactylus in Turkey is that in Keban Dam Lake, Elazığ [27].

Lake sediment represents an important sink for trace metals in aquatic systems, and metal concentrations in sediment can be several orders of magnitude greater than in the overlying water $[28,29]$. Researchers determined some trace element concentration in water and sediment samples of Keban Dam Lake. Average Zn concentration was measured as $1.28 \mathrm{ppm}$ in water samples and average concentration of $\mathrm{Zn}$, $\mathrm{Cu}, \mathrm{Cr}, \mathrm{Co}$, and $\mathrm{Ni}$ in sediment samples as 1473, 32.7, 198, 50, and 198 ppm, respectively [30].

In aquatic systems, crayfish have been a widespread importance to monitor metals and other contaminants [31], because of consuming widely and increasingly in human diets in the world [32]. Most crayfish are omnivorous benthic feeders living in close contact with the sediment and taking a variety of both animal and plant material [33, 34]. Few data are available on trace metal concentrations in benthic invertebrates from Keban Dam Lake, Elazı ğ, Turkey. In the present study, freshwater crayfish (A. leptodactylus) were used as the bioindicator organisms for monitoring and assessment of the water quality of the Keban Dam Lake for trace metals. Because they are closely associated with surficial sediments, and their effective bioaccumulation capacity of toxic metals has potential for transferring contaminants up the food web to human consumers.

In this study, the concentrations of trace elements determined were at permissible levels set by Turkish legislation in all years. No distinctive bioaccumulation trend was observed among years for any trace elements studied. Bioaccumulation of cooper, zinc, and mercury has a decreasing trend between 2006 and 2009 and then periods have showed increasing trend. But, for $\mathrm{Hg}$ and $\mathrm{Pb}$, there is an increase in bioaccumulation level in last two years. That increased level can be associated with increasing cage aquaculture facilities and agricultural activities around sampling area. Similarly [35] reported that the aquaculture industries such as cage aquaculture facilities may discharge many chemical pollutants like trace elements and PAHs to aquatic environment especially due to the use of antibiotic, agrochemicals formulated feed.

\section{Conclusion}

In this study, the results of trace elements concentrations in A. leptodactylus which were captured from Keban Dam Lake between 2006 and 2012 were reported. Our results showed that bioaccumulation can occur in edible tissues. This study will provide significant data for further water quality monitoring studies to establish effects of trace element presence on living organisms in Keban Dam Lake area.

\section{Conflict of Interests}

The authors declare that there is no conflict of interests regarding the publication of this paper.

\section{Acknowledgments}

This study was carried out by the support of the Provincial Directorate of Food, Agriculture, and Livestock in Tunceli (Turkey). The authors are thankful to all members of the Provincial Directorate of Food, Agriculture, and Livestock in Tunceli for their help and cooperation.

\section{References}

[1] A. Suárez-Serrano, C. Alcaraz, C. Ibáñez, R. Trobajo, and C. Barata, "Procambarus clarkii as a bioindicator of heavy metal pollution sources in the lower Ebro River and Delta," Ecotoxicology and Environmental Safety, vol. 73, no. 3, pp. 280-286, 2010.

[2] O. Kaplan, N. C. Yildirim, N. Yildirim, and M. Cimen, "Toxic elements in animal products and environmental health," Asian Journal of Animal and Veterinary Advances, vol. 6, no. 3, pp. 228-232, 2011.

[3] F. J. Sánchez, M. D. G. Gil, N. P. Sánchez, and J. L. Martinez, "Determination of heavy metals in crayfish by ICP-MS with a microwawe-assisted digestion treatment," Ecotoxicology and Environmental Safety, vol. 54, pp. 223-228, 2003. 
[4] M. Ural, N. Yildirim, D. Danabas et al., "Some heavy metals accumulation in tissues in Capoeta umbla (Heckel, 1843) from Uzuncayir Dam Lake (Tunceli, Turkey)," Bulletin of Environmental Contamination and Toxicology, vol. 88, no. 2, pp. 172-176, 2012.

[5] Agency for Toxic Substances and Disease Registry (ATSDR), Toxicological Profile for Copper, U.S. Department of Health and Human Services, Atlanta, Ga, USA, 2004.

[6] Agency for Toxic Substances and Disease Registry (ATSDR), Toxicological Profile for Cadmium, U.S. Department of Health and Human Services, Atlanta, Ga, USA, 2011.

[7] Agency for Toxic Substances and Disease Registry (ATSDR), Toxicological Profile for Lead, U.S. Department of Health and Human Services, Atlanta, Ga, USA, 2007.

[8] Agency for Toxic Substances and Disease Registry (ATSDR), Toxicological Profile for Mercury, Atlanta, Ga, USA, 1999.

[9] H. A. Schroeder, A. P. Nason, I. H. Tipton, and J. J. Balassa, "Essential trace metals in man: zinc. Relation to environmental cadmium," Journal of Chronic Diseases, vol. 20, no. 4, pp. 179210, 1967.

[10] M. E. Wastney, R. L. Aamodt, W. F. Rumble, and R. I. Henkin, "Kinetic analysis of zinc metabolism and its regulation in normal humans," The American Journal of Physiology, vol. 251, no. 2, pp. 398-410, 1986.

[11] L. E. Cuevas and A. Koyanagi, "Zinc and infection: a review," Annals of Tropical Paediatrics, vol. 25, no. 3, pp. 149-160, 2005.

[12] D. K. Nordstrom, "Worldwide occurrences of arsenic in ground water," Science, vol. 296, no. 5576, pp. 2143-2145, 2002.

[13] A. H. Smith, C. Hopenhayn-Rich, M. N. Bates et al., "Cancer risks from arsenic in drinking water," Environmental Health Perspectives, vol. 97, pp. 259-267, 1992.

[14] J. A. Centeno, P. B. Tchounwou, A. K. Patlolla et al., "Environmental pathology and health effects of arsenic poisoning: a critical review," in Managing Arsenic in the Environment: From Soil to Human Health, R. Naidu, E. Smith, G. Owens, P. Bhattacharya, and P. Nadebaum, Eds., pp. 311-327, CSIRO, Melbourne, Australia, 2006.

[15] Q. D. Le, K. Shirai, D. C. Nguyen, N. Miyazaki, and T. Arai, "Heavy metals in a tropical eel Anguilla marmorata from the central part of vietnam," Water, Air, and Soil Pollution, vol. 204, no. 1-4, pp. 69-78, 2009.

[16] G. Bagatto and M. A. Alikhan, "Copper, cadmium, and nickel accumulation in crayfish populations near copper-nickel smelters at Sudbury, Ontario, Canada," Bulletin of Environmental Contamination and Toxicology, vol. 38, no. 3, pp. 540-545, 1987.

[17] D. J. H. Phillips and P. S. Rainbow, Biomonitoring of Trace Aquatic Contaminants, vol. 388 of Ettore Majorana International Science Series, Chapman and Hall, London, UK, 1993.

[18] D. Danabas, F. Benzer, O. Kaplan, and N. C. Yildirim, "Levels of copper in liver, muscle and gill tissues in Capoeta trutta (Heckel, 1843) from Munzur River, Turkey," African Journal of Agricultural Research, vol. 6, no. 7, pp. 1909-1912, 2011.

[19] G. B. Masters, Introductions to Environmental Engineering and Science, Prentice Hall, Upper Saddle River, NJ, USA, 1997.

[20] O. Barim and M. Karatepe, "The effects of pollution on the vitamins $\mathrm{A}, \mathrm{E}, \mathrm{C}, \beta$-carotene contents and oxidative stress of the freshwater crayfish, Astacus leptodactylus," Ecotoxicology and Environmental Safety, vol. 73, no. 2, pp. 138-142, 2010.

[21] A. Ç. K. Benli, R. Sarıkaya, A. Sepici-Dincel, M. Selvi, D. Şahin, and F. Erkoç, "Investigation of acute toxicity of $(2,4-$ dichlorophenoxy)acetic acid (2,4-D) herbicide on crayfish
(Astacus leptodactylus Esch. 1823)," Pesticide Biochemistry and Physiology, vol. 88, no. 3, pp. 296-299, 2007.

[22] A. T. Khan, D. M. Forester, and H. W. Mielke, "Heavy metal concentrations in two populations of crayfish," Veterinary and Human Toxicology, vol. 37, no. 5, pp. 426-428, 1995.

[23] P. A. Schilderman, E. J. C. Moonen, L. M. Maas, I. Welle, and J. C. S. Kleinjans, "Use of crayfish in biomonitoring studies of environmental pollution of the river Meuse," Ecotoxicology and Environmental Safety, vol. 44, no. 3, pp. 241-252, 1999.

[24] M. Guoda, "Bioaccumulation of heavy metals in noble crayfish (Astacus astacus L.) tissues under aquculture conditions," Ecologija, vol. 2, pp. 79-82, 2002.

[25] U. Güner, "Heavy metal effects on $\mathrm{P}, \mathrm{Ca}, \mathrm{Mg}$, and total protein contents in embryonic pleopodal eggs and stage-1 juveniles of freshwater crayfish Astacus leptodactylus (Eschscholtz, 1823)," Turkish Journal of Biology, vol. 34, no. 4, pp. 405-412, 2010.

[26] NMKL, "Nordic committee on food analysis," method no. 161, Postboks 8156 Dep. N-0033, Oslo, Norway, pp. 1-8, 1998.

[27] M. M. Harlioǧlu, Ö. Barim, I. Türkgülü, and A. G. Harlioǧlu, "Potential fecundity of an introduced population, Keban Dam Lake, Elaziğ, Turkey, of freshwater crayfish, Astacus leptodactylus leptodactylus (Esch., 1852)," Aquaculture, vol. 230, no. 1-4, pp. 189-195, 2004.

[28] S. N. Luoma, "Bioavailability of trace metals to aquatic organisms-a review," Science of the Total Environment, vol. 28, pp. 1-22, 1983.

[29] M. C. Eimers, R. D. Evans, and P. M. Welbourn, "Cadmium accumulation in the freshwater isopod Asellus racovitzai: the relative importance of solute and particulate sources at trace concentrations," Environmental Pollution, vol. 111, no. 2, pp. 247 253, 2001.

[30] F. Kulahci and M. Doğru, "Physical and chemical investigation of water and sediment of the Keban Dam Lake, Turkey-part 2: distribution of radioactivity, heavy metals and major elements," Journal of Radioanalytical and Nuclear Chemistry, vol. 268, no. 3, pp. 529-537, 2006.

[31] J. Burger, K. F. Gaines, C. S. Boring et al., "Metal levels in fish from the Savannah river: potential hazards to fish and other receptors," Environmental Research, vol. 89, no. 1, pp. 85-97, 2002.

[32] Z. Zhang, L. He, J. Li, and Z. B. Wu, "Analysis of heavy metals of muscle and intestine tissue in fish-in banan section of chongqing from three gorges reservoir, China," Polish Journal of Environmental Studies, vol. 16, no. 6, pp. 949-958, 2007.

[33] J. Love and J. F. Savino, "Crayfish (Orconectes virilis) predation on zebra mussels (Dreissena polymorpha)," Journal of Freshwater Ecology, vol. 8, pp. 253-259, 1993.

[34] M. Matthews, J. D. Reynolds, and M. J. Keatinge, "Macrophyte reduction and benthic community alteration by the crayfish, Austropotamobius pallipes (Lereboullet)," Freshwater Crayfish, vol. 9, pp. 289-299, 1993.

[35] Y. Shahrizat, Distribution and accumulation of heavy metals in fish cage system in Linggi, Estuary, Malaysia [M.S. thesis], Faculty of Science, University of Putra Malaysia, 2005. 

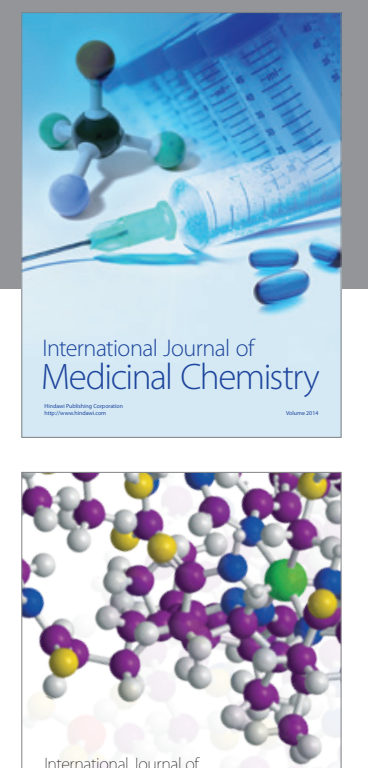

\section{Carbohydrate} Chemistry

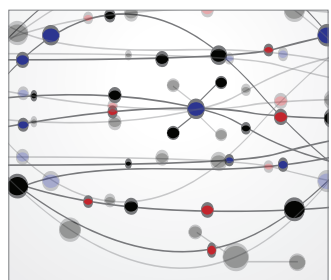

The Scientific World Journal
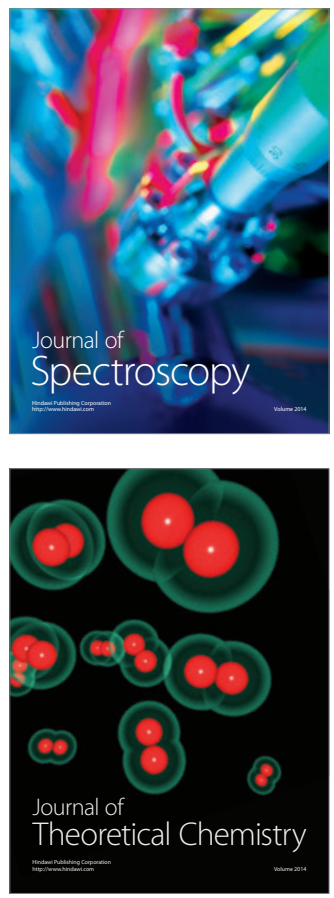
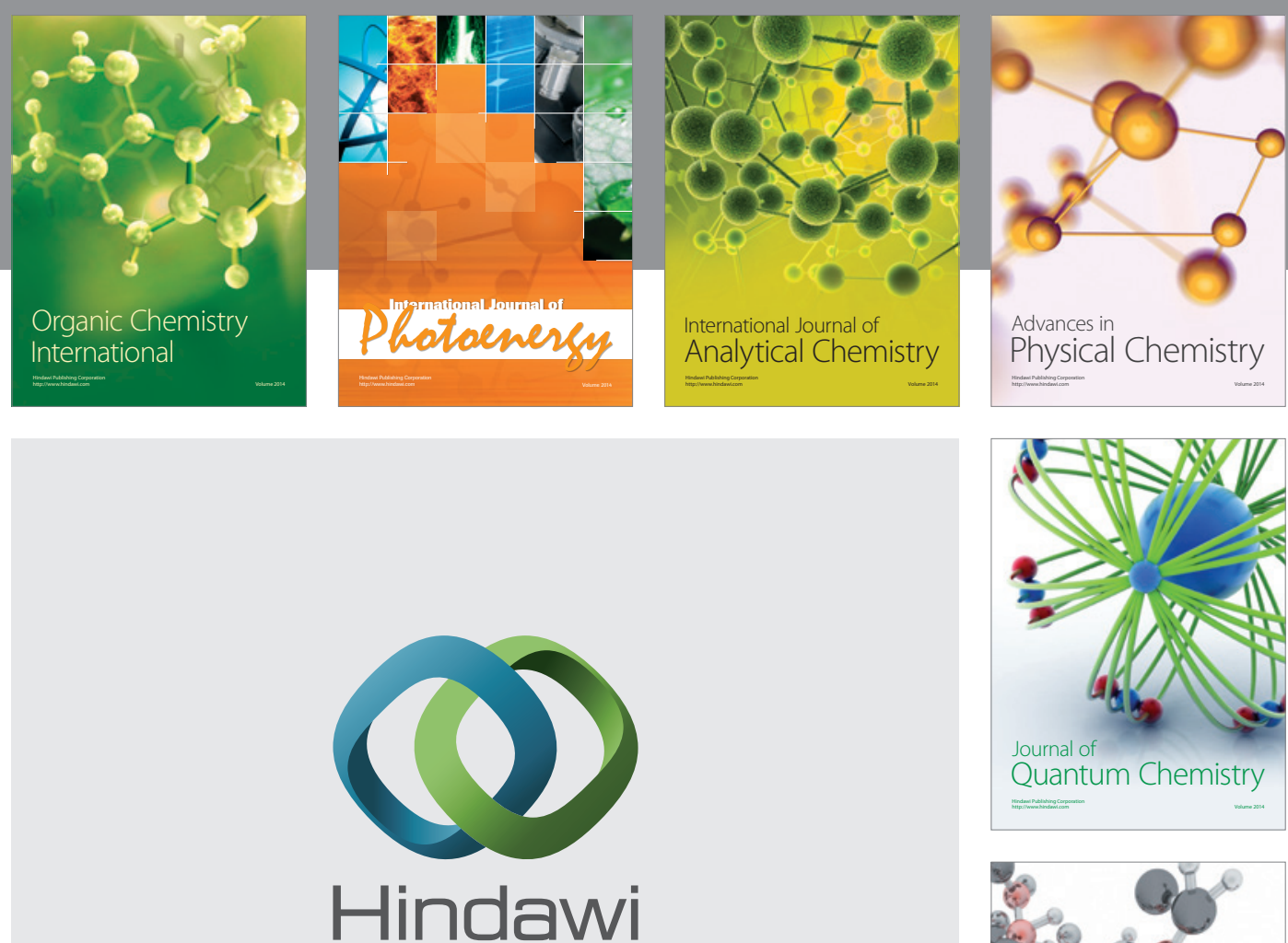

Submit your manuscripts at

http://www.hindawi.com

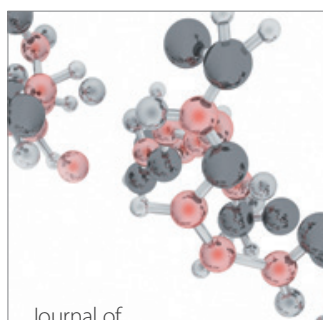

Analytical Methods

in Chemistry

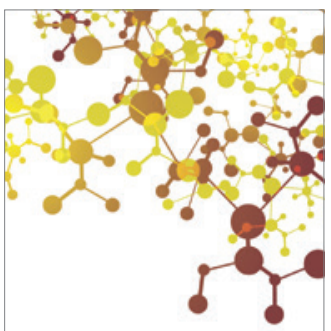

Journal of

Applied Chemistry

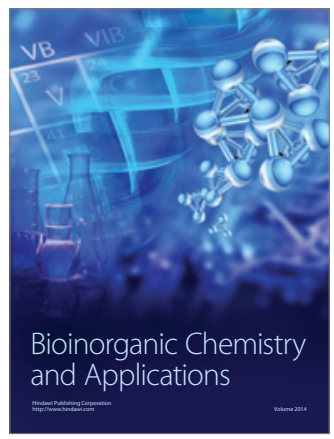

Inorganic Chemistry
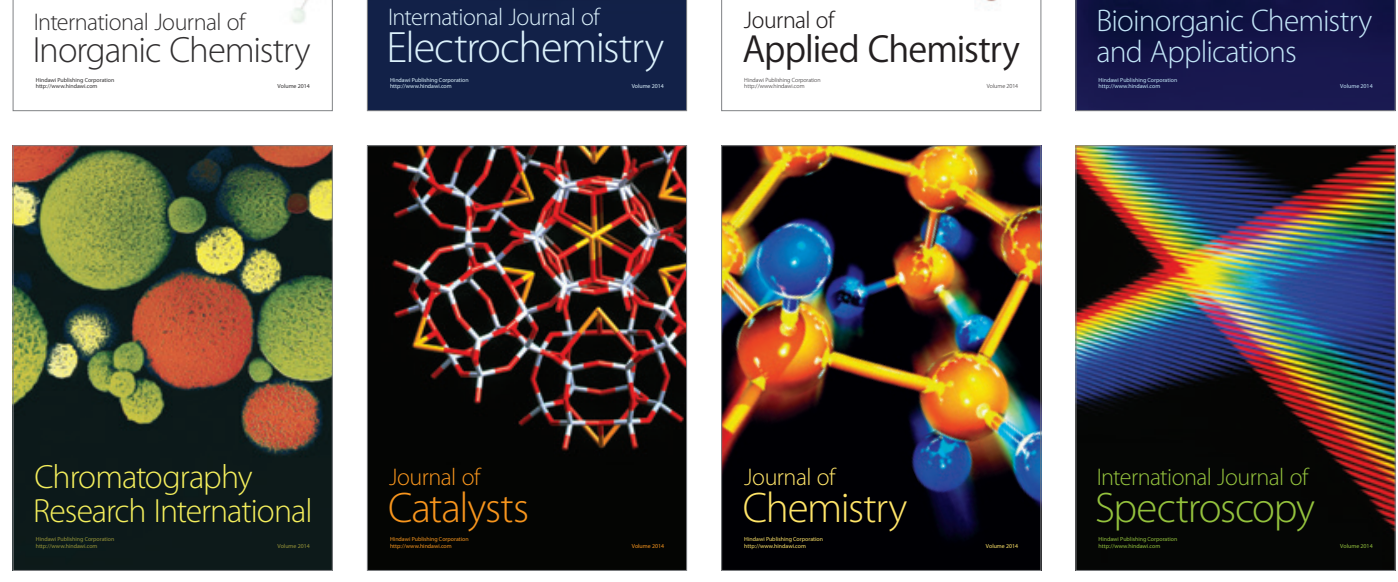